\title{
OSOBY Z NIEPEŁNOSPRAWNOŚCIA W DZIEŁACH SZTUKI W UJĘCIU PEDAGOGICZNYM
}

Streszczenie: Postawy wobec osób z niepełnosprawnością są częstym tematem prac badawczych. W niniejszym artykule autorka skupia się na możliwości kształtowania pozytywnych postaw wobec takich osób poprzez kontakt z dziełami sztuki. Wychowanie przez sztukę potraktowane zostało jako narzędzie do pracy z uczniami, które ma szansę zmienić postrzeganie niepełnosprawności poprzez pryzmat stereotypów.

Słowa kluczowe: postawy, osoby niepełnosprawne, wychowanie przez sztukę

\section{Wprowadzenie}

Wiele artykułów porusza temat twórczości osób z niepełnosprawnością. Podejmowany on jest w kontekście terapii zajęciowej czy arteterapii, które mają służyć rehabilitacji zarówno fizycznej, jak i społecznej. Nie jest mi znane natomiast żadne opracowanie poświęcone wizerunkowi osób z niepełnosprawnością w sztuce. Takie dzieła mogą stać się narzędziem w rękach pedagoga. W niniejszym opracowaniu przedstawię możliwość wykorzystania wychowania przez sztukę w pracy z uczniami, aby w efekcie wykształcić u nich pozytywne postawy wobec osób z niepełnosprawnością. Mam nadzieję, że te teoretyczne rozważania staną się inspiracją w pracy wychowawczej i w przyszłości zostaną uzupełnione o badania empiryczne.

\section{Postawy i stereotypy}

Zagadnienie postaw ma charakter interdyscyplinarny. Tematem tym zajmują się psychologowie i socjologowie, ale jest on także interesujący z punktu widzenia pedagogiki. Postawa według Bogdana Wojciszke to tendencja do pozytywnego lub negatywnego wartościowania danego obiektu przez człowieka (Wojciszke 2002). Stanisław Mika przyjmuje podejście socjologiczne i definiuje postawę jako „względnie trwały stosunek emocjonalny lub oceniający do przedmiotu lub dyspozycję 
do występowania takiego stosunku, wyrażającą się w kategoriach pozytywnych, negatywnych bądź neutralnych" (Mika 1984, s. 113-114). Te dwie definicje rozpatrują postawę w kategoriach wartości pozytywnych i negatywnych, a u Miki również neutralnych. Dodatkowo ten ostatni badacz zwraca uwagę, że postawa to pewien stosunek emocjonalny do danego przedmiotu.

Obecnie przyjmuje się, że postawy składają się z trzech komponentów: poznawczych, czyli informacji o przedmiocie; afektywnych, mających sprecyzowaną siłę i kierunek; indywidualnych działań wobec przedmiotu postawy, czyli zachowania (Mika 1984). Podczas kreowania postaw ważna jest więc zarówno wiedza, jak i stosunek emocjonalny do danego przedmiotu oraz tendencja do pewnych zachowań, co łącznie determinuje zachowanie w stosunku do przedmiotu określonej postawy.

Ze względu na treść przedmiotową postawy dzieli się na personalne, rzeczowe oraz niepersonalne i nierzeczowe. Pierwsza grupa to postawy wobec osób, które dzieli się na intrapersonalne (względem siebie samego), interpersonalne (w stosunku do innych osób) oraz grupowe (wobec grup społecznych). Druga kategoria postaw dotyczy rzeczy, takich jak mieszkanie, samochód, książki itp. Postawy niepersonalne i nierzeczowe obejmują normy moralne, wyznawane wartości czy teorie naukowe (Mądrzycki 1997). Uwzględniając powyższy podział i biorąc pod uwagę temat niniejszego opracowania, uznaję, że w dalszej części artykułu rozpatrywana będzie postawa personalna grupowa.

Postawy można kształtować, zmieniać ich siłę lub znak. Kształtowanie postaw odbywa się wobec wcześniej nieznanego przedmiotu. Jeżeli pojawia się coś nowego, co nie było do tej pory znane, to mamy do czynienia z kształtowaniem postawy. Zmiana siły to jedynie korekta danej postawy z formy łagodnej do bardziej nasilonej lub odwrotnie. Nie ma ona jednak wpływu na wartościowanie danego zjawiska. Jeżeli więc dany przedmiot odbierany jest jako coś pozytywnego, to przy zmianie siły może być odebrany bardziej lub mniej pozytywnie. Zmiana znaku wydaje się najtrudniejsza do przeprowadzenia. Polega na zmianie postawy z wartości ujemnej na dodatnią lub odwrotnie (Mika 1984). Jak podaje raport Dzieci w Polsce opracowany przez UNICEF, w 2011 roku liczba uczniów w szkołach podstawowych i gimnazjalnych wynosiła prawie 3,5 miliona, z czego ok. 110 tysięcy stanowiły osoby z niepełnosprawnością. Połowa z nich uczęszczała do szkół specjalnych (Falkowska, Telusiewicz-Pacak 2013). Uczniowie z niepełnosprawnością stanowią nieco ponad $3 \%$ wszystkich uczniów. Biorąc pod uwagę te dane, w artykule posługiwać się będę terminem kształtowania postaw, gdyż kontakt z uczniami z niepełnosprawnością w szkołach podstawowych i gimnazjalnych jest ograniczony. Termin ten lepiej odzwierciedli proces zmiany w postawie wobec osób z niepełnosprawnością, jaki ma zajść w uczniach poprzez kontakt z dziełami sztuki.

Bez względu na to, czy chcemy ukształtować w pozytywny sposób postawę wobec danego przedmiotu, czy też zmienić już istniejącą, istotne są czynniki, które mogą się temu przysłużyć. Należy przy tym zaznaczyć, że znacznie łatwiej jest ukształtować nową postawę lub zmienić taką, której bliżej jest do postawy 
neutralnej, aniżeli próbować zmienić postawę negatywną w pozytywną. Herbert C. Kelman wyróżnił trzy rodzaje zmiany postaw. Pierwsza z nich to uleganie. Osoba dokonuje zmiany, ponieważ obawia się kary lub liczy na nagrodę. Druga to identyfikacja. Chęć utrzymania znajomości z daną osobą albo grupą jest na tyle silna, że osoba przyjmuje jej wartości i upodabnia się do niej. Trzeci rodzaj to internalizacja, która zachodzi wówczas, gdy osoba uznaje daną postawę za słuszną (Ceranek-Dadas, Neumann-Schmidtke 2005). Wychowawca powinien prowadzić zajęcia w taki sposób, aby uczniowie uznali prezentowaną przez niego postawę za właściwą i ją przyjęli.

Należy wspomnieć, że nie zawsze postawa jest zgodna z zachowaniem człowieka. Allan W. Wicker wymienia dwie kategorie czynników, które mogą przyczyniać się do zaistnienia związku pomiędzy zachowaniem a postawą. Mają one charakter osobowościowy lub sytuacyjny. Do czynników o charakterze osobowościowym zaliczyć można między innymi postawy sprzeczne z tymi, których związek z zachowaniem badamy, lub których motywy są sprzeczne z daną postawą. Jeśli zaś chodzi o czynniki sytuacyjne, warto wymienić dwa. Pierwszy z nich to przepisy dotyczące ról, które określają zachowanie człowieka, a mogą być sprzeczne z jego postawami. Drugi czynnik to obecność innych osób, przy których człowiek obawia się zachowania zgodnego z jego postawą (Mika 1984).

Kolejną kwestią są stereotypy. Postawy i zachowania człowieka zależne są od tego, w jaki sposób odbiera i rozumie otaczający go świat. Wszelkie wydarzenia są interpretowane indywidualnie, przez co jedna sytuacja może być różnie odbierana przez poszczególne osoby. Co więcej, jedna osoba może różnie interpretować dane zdarzenie w zależności od warunków zewnętrznych. Eliot Aronson definiuje stereotyp jako „nadmierne uogólnienie - przypisywanie identycznych cech każdej osobie należącej do danej grupy, bez uwzględnienia istniejących w rzeczywistości różnic między członkami tej grupy" (Aronson 1978, s. 232). Stereotypy rozumie jako uproszczone postrzeganie świata, ale też element niepozwalający na dostrzeżenie indywidualnych różnic w obrębie konkretnej grupy ludzi, jak na przykład rasa, wyznanie, pochodzenie społeczne i inne. W psychologii społecznej stereotyp jest składnikiem postaw człowieka.

Stereotypy nie zawsze muszą być negatywne, gdyż definiuje się je jako zespół przekonań dotyczących pewnych grup społecznych. Przekonania te mogą być prawdziwe lub nie, jak również pozytywne lub negatywne (Lee i in. 1995, za: Kurcz 2001). Posługiwanie się stereotypem z punktu widzenia człowieka, który go używa, wydaje się bardzo funkcjonalne. Dzięki niemu może on usprawiedliwiać zachowania istniejącym porządkiem społecznym, oszczędzając przy tym czas, jaki należałoby poświęcić na poznanie drugiej osoby. Jednak należy pamiętać, że stereotypy mogą być społecznie szkodliwe, gdyż przyczyniają się do niesprawiedliwej oceny człowieka i do zaostrzania konfliktów społecznych (Wojciszke 2002). Istnieje wiele stereotypów dotyczących osób z niepełnosprawnością, które w większości wpływają na ich negatywny odbiór przez społeczeństwo. W rezultacie osoby 
z niepełnosprawnością są dyskryminowane, marginalizowane, a ostatecznie wykluczane z życia społecznego.

\section{Osoby z niepełnosprawnością $\mathrm{w}$ dziełach sztuki}

Koncepcja wychowania przez sztukę stworzona przez Bogdana Suchodolskiego zakłada czerpanie ze sztuki nie tylko wartości estetycznych, ale też takich, które kształtować będą całego człowieka. „Sztuka pokazuje nie tylko różnorodność życia i jedność prawdziwych, humanistycznych treści, pokazuje równocześnie to, co nazwano «dolą człowieczą», pokazuje po prostu drugiego człowieka w perspektywie nas samych, pokazuje go jako tożsamego z nami, chociaż tak różnego od nas" (Suchodolski 1965, s. 29). Bogdan Suchodolski wskazuje na funkcję sztuki, polegającą na pokazaniu drugiego człowieka, ale w sposób pełny. Sztuka pozwala dostrzec zarówno rzeczywistość zewnętrzną, jak i wewnętrzną, ludzką. W koncepcji wychowania przez sztukę pełni ona rolę elementu łamiącego schematy i wzory, które narosły w naszej rzeczywistości. Sztuka ma pobudzać, przełamywać stereotypy, uczyć aktywności i rozwiązywania problemów (Wojnar 1976). Inną jej funkcją jest oddziaływanie na życie emocjonalne człowieka. Dzięki kontaktom z dziełami sztuki ma on możliwość zwiększenia i wzmacniania przeżywanych doświadczeń (Wojnar 1966).

Koncepcję tę można wykorzystać podczas lekcji dotyczących osób z niepełnosprawnością. Dzięki sztuce, która pokazuje drugiego człowieka jako Innego, a jednak takiego samego jak my, nauczyciel ma możliwość zmiany czy też kreowania pozytywnej postawy wobec osób z niepełnosprawnością. Odpowiednie wykorzystanie wizerunku takich osób w sztuce daje szanse na przełamanie wobec nich negatywnych stereotypów. W tym miejscu wspomnę o niektórych dziełach sztuki, jakie wychowawcy mogą wykorzystać podczas lekcji dotyczących niepełnosprawności. Zaprezentowane obrazy to jedynie propozycje. Stanowią one przykłady twórczości wybitnych artystów, w tym twórców, którzy sami borykali się z niepełnosprawnością.

Twórczość Fridy Kahlo to pierwsze obrazy, jakie przychodzą do głowy, gdy myśli się o niepełnosprawności w sztuce. Artystka zaczęła tworzyć tuż po tragicznym wypadku, który na zawsze zmienił jej życie. W jego wyniku doznała licznych uszkodzeń ciała, w tym złamania kręgosłupa, a przez całe życie przeszła ponad 30 operacji. Wypadek uniemożliwił jej zostanie matką i rzutował zarówno na całe życie, jak i twórczość. Sztuka była dla niej odskocznią od przykrych doświadczeń i miesięcy spędzanych w gipsie. Przepełniona jest jej niepełnosprawnością. Takie obrazy jak Złamana kolumna czy Autoportret z portretem doktora Farilla są pretekstem do rozmowy o niepełnosprawności. Życie Fridy to doskonały przykład na to, jak można czerpać z życia pełnymi garściami pomimo problemów z ciałem. Jej silna osobowość, stojąca w opozycji do niepełnosprawnego ciała, przełamuje stereotyp osoby niepełnosprawnej, która jest zależna od innych i bez innych sobie 
nie radzi. Malarka w swoich obrazach ukryła emocje, jakie towarzyszyły jej codziennie od chwili wypadku. Ich rozpoznanie może być pierwszym elementem pracy z obrazami.

Vincent van Gogh, wybitny przedstawiciel postimpresjonizmu, zmagał się z padaczką oraz najprawdopodobniej z zaburzeniami afektywnymi dwubiegunowymi. W jego pracach niepełnosprawność nie pojawia się jako temat, nie jest pokazana wprost. Gwiaździsta noc to obraz, na którym z dużą intensywnością przedstawione są gwiazdy. Kolor żółty pojawia się również w innych pracach van Gogha, między innymi w Słonecznikach. Przypuszcza się, że widzenie świata przez pryzmat żółtych plam otoczonych koronami to efekt przyjmowania dużych dawek leku z naparstnicy, który w czasach malarza był aplikowany chorym na epilepsję (Wolf 2001). Gwiaździsta noc została namalowana nie z natury, a z wyobraźni, i posiada szereg interpretacji, z których niektóre wykluczają się nawzajem. Obraz powstał podczas pobytu van Gogha w szpitalu psychiatrycznym (Field 2006). Wychowawca ma możliwość wykorzystania tego dzieła sztuki, aby przybliżyć życie osób chorujących na padaczkę i zaburzenia afektywne dwubiegunowe. Interesujące jest zestawienie kolorowych, żywych obrazów malarza z jego biografią, która naznaczona jest nie tylko chorobą, ale również brakiem uznania wśród publiczności. Kontrast ten można wykorzystać do przybliżenia zaburzeń afektywnych dwubiegunowych, które charakteryzują się naprzemiennym występowaniem stanów manii i depresji.

Kontrowersyjne może wydawać się wykorzystanie przez nauczycieli twórczości Artura Żmijewskiego. Jego prace, wchodzące w skład wystawy Oko za oko z 1998 roku, prezentują hybrydowe połączenia osób z niepełnosprawnością $\mathrm{z}$ osobami pełnosprawnymi. Osoby z niepełnosprawnością są tworzywem w ręku rzeźbiarza, który zastępuje ich niepełnosprawność pełnosprawnymi elementami zdrowych ciał. Twórca podkreśla, że nie należy patrzeć na osoby z niepełnosprawnością przez pryzmat osoby w pełni zdrowej. Uważa on, że dla osób z niepełnosprawnością to ludzie pełnosprawni są inni, odmienni, a wręcz ułomni (Monkiewicz 2005). W moim przekonaniu takie podejście wzbudzi zainteresowanie u uczniów. Odwrócenie myślenia, tak aby to pełnosprawny był ułomny, a niepełnosprawny zdrowy, może być momentem przełomowym w postrzeganiu przez nich osób $\mathrm{z}$ niepełnosprawnością, ale także postrzeganiu ich samych.

Posiłek ślepego mężczyzny, pochodzący z tzw. okresu błękitnego Pabla Picassa, to obraz, który można wykorzystać podczas zajęć dotyczących osób niewidomych i słabowidzących. Okres błękitny w twórczości malarza został zapoczątkowany samobójczą śmiercią jego przyjaciela. Dominujące w obrazach odcienie niebieskiego, a także tematyka oscylująca wokół biedy, niepełnosprawności i starości wskazują na głębokie przeżywanie straty. Chleb i wino na wspomnianym obrazie to symbole charakterystyczne dla religii katolickiej. Obraz przedstawia mężczyznę, który niczym Chrystus spożywa swoją ostatnią, skromną wieczerzę, aby za chwilę umrzeć. Ten wzruszający portret dzięki wychowawcy może stać się narzędziem 
kreowania pozytywnej postawy wobec osób niewidomych i początkiem rozmowy o osobach dotkniętych tym rodzajem niepełnosprawności.

Przypuszcza się, że w renesansie i baroku licznie portretowano dzieci z zespołem Downa. Najprawdopodobniej najstarszym przedstawieniem tego typu jest postać anioła adorującego Jezusa w obrazie nieznanego flamandzkiego malarza pt. Pokłon Dziecięciu Bożemu z 1515 roku (Levitas, Reid 2003). Charakterystyczne dla tej choroby cechy można rozpoznać w twarzach amorków, aniołów czy małego Jezusa. Dostrzec je można między innymi w Madonnie Trivulzio pędzla Fra Filippa Lippiego, Madonnie z Dzieciątkiem Andrei Mantegni czy w obrazach o tym samym tytule Petera Paula Rubensa i Jana Brueghla młodszego. Malarze tamtego okresu najprawdopodobniej decydowali się na wybranie modela spośród osób z zespołem Downa, bo wiadomo było, iż nie zrobi on w życiu niczego niewłaściwego. Artyści obawiali się o własne sumienie w przypadku, gdyby model pozujący jako Jezus w przyszłości okazał się złodziejem lub popełnił inną zbrodnię. Osoby z zespołem Downa były postrzegane jako nieszkodliwe i prowadzące spokojnie życie. Nie traktowano ich jak niepełnosprawnych. Dla społeczności były to jednostki, które pracowały i myślały wolniej od innych, ale dawały sobie radę w życiu codziennym (Pospiszil, Dawno...). Z ludźmi dotkniętymi zespołem Downa większość uczniów miała lub będzie miała styczność. Dlatego w tym wypadku wychowawca ma za zadanie zmienić neutralną lub negatywną postawę w pozytywną. Może okazać się to trudne, gdy młodzież będzie miała już swoje przekonania na ten temat. Jednak posłużenie się dziełami sztuki, a także przedstawienie, w jaki sposób odbierano osoby z zespołem Downa kiedyś, może stać się pomocne.

\section{Zalecenia pedagogiczne}

Warto wspomnieć o kompetencjach nauczyciela, który chciałby prowadzić tego rodzaju lekcje. Przede wszystkim osoba podejmująca temat niepełnosprawności musi mieć świadomość, czym jest niepełnosprawność i jakie są jej rodzaje. Wiedza nauczyciela powinna być rzetelna i nie bazować na stereotypach. Znajomość koncepcji wychowania przez sztukę lub wychowania estetycznego jest niezbędna, jeżeli chce on wykorzystać dzieła sztuki jako narzędzie w kreowaniu pozytywnych postaw wobec osób z niepełnosprawnością. Należy wspomnieć też o podstawowej wiedzy z zakresu historii sztuki, która pomoże mu w poprowadzeniu takiej lekcji. Nauczyciel musi znać najważniejsze fakty dotyczące dzieła sztuki i jego autora, ale także ciekawostki, które pomogą rozpocząć lekcję i zachęcić uczniów do aktywnego słuchania. Ostatnim elementem jest wiedza z zakresu psychologii społecznej, związana $z$ takimi pojęciami jak postawa, kreowanie i zmiana postaw. Osoba, która podejmie się poprowadzenia tego rodzaju zajęć, musi mieć szeroką wiedzę z zakresu pedagogiki, psychologii, estetyki i historii sztuki. Niezbędne jest więc wykształcenie u pedagogów chęci jej pogłębiania i poszerzania horyzontów o inne dziedziny nauki. 
W interpretacji dzieł sztuki niezwykle ważna jest elastyczność. Każde bowiem może zostać zinterpretowane inaczej, w zależności od tego, kto jest widzem. Dzieło sztuki to pośrednik w dialogu pomiędzy twórcą a odbiorcą. Jego interpretacja zależeć będzie od indywidualnych przeżyć odbiorcy (Ingarden 1970). Jednak dialog nie może być pełny bez poznania twórcy, który stworzył dane dzieło sztuki. Istotna jest jego biografia, ale także miejsce i czas powstania dzieła. Dlatego tak ważnym elementem w pracy wychowawczej jest nie tylko udostępnianie dzieł sztuki uczniom, ale również ich uprzystępnianie, dzięki czemu zrozumieją i przyswoją zawarte w nich wartości. Historycy sztuki nie zgadzają się ze sobą w kwestii przedstawień osób z zespołem Downa w malarstwie renesansowym i barokowym, tak samo jak nie zgadzają się co do interpretacji Panien dworskich Diega Velázqueza czy Portretu małżonków Arnolfinich Jana van Eycka i wielu innych dzieł sztuki. $\mathrm{Z}$ perspektywy wychowawcy ważne jest, aby z jednej strony pozwolić uczniom wypowiedzieć się na dany temat, a z drugiej podkreślić, że dzieła sztuki są różnie interpretowane. Przede wszystkim jednak powinien on osadzić dzieło w kontekście historycznym, społecznym i biograficznym twórcy, aby uczniowie mogli sami wysnuć interpretacje.

Każde dzieło sztuki jest zbiorem elementów, które łącznie tworzą obraz niepowtarzalny. Analizując je, niezbędne jest zarówno spojrzenie całościowe, jak i zwrócenie uwagi właśnie na te poszczególne elementy (Szuman 1969). Podejmując temat osób z niepełnosprawnością w interpretowanym dziele sztuki, na pierwszy plan należy wysunąć kwestię osób niepełnosprawnych. W trakcie uprzystępniania danego dzieła sztuki szczególną uwagę trzeba zwrócić na temat zajęć i omówić niepełnosprawność w kontekście wybranego obrazu. Przed uprzystępnieniem go warto rozpocząć dyskusję o osobach z niepełnosprawnością, kładąc nacisk na rodzaj niepełnosprawności, który chcemy przybliżyć dzięki zapoznaniu uczniów z wybranym dziełem sztuki.

Kontakt z obrazem ma być wprowadzeniem do tematyki niepełnosprawności. Jednak warto tak zaplanować pracę wychowawczą, aby było ono użytecznym narzędziem podczas całych zajęć. W zależności od wybranego dzieła sztuki, a tym samym rodzaju niepełnosprawności, zajęcia mogą zostać poprowadzone innym torem. Przy planowaniu ich przebiegu niezbędne jest uwzględnienie wieku uczniów, a tym samym ich możliwości poznawczych. W przypadku wybrania obrazów stworzonych przez artystów z niepełnosprawnością, jak Frida Kahlo czy Vincent van Gogh, tematyka zajęć może być skupiona na przełamywaniu trudności. Ciekawym elementem będzie stworzenie przez uczniów listy własnych barier, które pokonują każdego dnia lub które chcieliby pokonać w przyszłości. Podkreślenie, że każdy $\mathrm{z}$ nas ma przeszkody do pokonania - bez względu na to, czy jest osobą w pełni sprawną, czy nie - zwróci uwagę nie na różnice pomiędzy nimi a osobami z niepełnosprawnością, a na podobieństwa. Wychowawca zamiast na różnicach skupi się na podobieństwach, co wzmocni pozytywny obraz osoby z niepełnosprawnością w oczach uczniów. Prace Artura Żmijewskiego, ze względu na występującą tam 
nagość, są przeznaczone dla starszych uczniów. W pracy z twórczością tego artysty kluczowe jest zrozumienie siebie i osoby $\mathrm{z}$ niepełnosprawnością $\mathrm{w}$ kontekście potrzeb i barier, jakie ma każdy człowiek bez względu na stan zdrowia. Wychowawca może w zajęciach wykorzystać dramę, skupiając się na ćwiczeniach opierających się na dotyku, bliskości, gdzie zachwianiu ulega tzw. bezpieczna strefa. Pracując z obrazem Pabla Picassa Posiłek ślepego mężczyzny, warto włączyć ćwiczenie, podczas którego uczniowie mają zasłonięte oczy i pozwalają prowadzić się partnerom. W ten sposób bardziej doświadczą, a tym samym lepiej zrozumieją, codzienne zmagania osób niewidomych.

Istnieje wiele możliwości wykorzystania dzieł sztuki w celu kreowania pozytywnych postaw wobec osób z niepełnosprawnością. Niezbędna jest przy tym wiedza wychowawcy i jego kreatywność, która pozwoli na przeprowadzenie ciekawych zajęć, na których uczniowie nie tylko zobaczą dzieło sztuki, ale również doświadczą go i przeżyją, przyswajając zawarte w nim wartości.

\section{Zakończenie}

Wychowawca we współczesnej szkole musi być osobą o wszechstronnych zainteresowaniach, posiadającą dużą wiedzę nie tylko z zakresu pedagogiki, ale także nauk pomocniczych. Dzięki swojemu hobby może nie tylko przekazać uczniom swoją pasję, ale także zaprezentować otwartość wobec odmienności. Osoby z niepełnosprawnością często żyją na marginesie codzienności. Pomimo coraz większej liczebności klas integracyjnych wielu uczniów boi się osób z niepełnosprawnością. Ta obawa dotyczy mnóstwa aspektów i wiąże się z licznymi stereotypami, jakie ciągle funkcjonują w społeczeństwie. Sztuka może stać się pomostem pomiędzy osobami pełnosprawnymi i niepełnosprawnymi. Dzięki dziełom sztuki uczeń może nie tylko doświadczyć przeżyć estetycznych, ale także pogłębić swoją wiedzę na temat niepełnosprawności, ucząc się przy tym empatii wobec osób nią dotkniętych.

\section{Bibliografia}

Aronson E. (1978). Człowiek - istota społeczna. Warszawa: Państwowe Wydawnictwo Naukowe.

Ceranek-Dadas A., Neumann-Schmidtke E. (2005). Postawy. W: Pilch T. (red.). Encyklopedia pedagogiczna XXI wieku, t. 4. Warszawa: Wydawnictwo Akademickie Żak.

Falkowska E., Telusiewicz-Pacak A. (red.). (2013). Dzieci w Polsce. Dane, liczby, statystyki. Warszawa: Polski Komitet Narodowy UNICEF.

Field D.M. (2006). Van Gogh. Edison: Chartwell Books Inc.

Ingarden R. (1970). Studia z estetyki, t. 3. Warszawa: Państwowe Wydawnictwo Naukowe. 
Kurcz I. (2001). Zmiana stereotypów: jej mechanizmy i granice. W: Kofta M., Jasińska-Kania A. (red.). Stereotypy i uprzedzenia. Uwarunkowania psychologiczne i kulturowe. Warszawa: Wydawnictwo Naukowe Scholar.

Lee Y.T., Jussim L.J., McCauley C.R. (1995). Stereotype accuracy: toward appreciating group differences. Washington: American Psychological Association.

Levitas A., Reid Ch. (2003). An angel with Down syndrome in sixteenth century flemish nativity painting. "American Journal of Medical Genetics”, 116A, s. 399-405.

Mądrzycki T. (1997). Psychologiczne prawidłowości kształtowania się postaw. Warszawa: Wydawnictwa Szkolne i Pedagogiczne.

Mika S. (1984). Psychologia społeczna. Warszawa: Państwowe Wydawnictwo Naukowe.

Monkiewicz D. (2005). Reprezentacje ciała $w$ latach 1968-20oo. W: Kochanowska-Reiche M., Winzen M. (red.). Duchowość i cielesność: skarby Muzeum Narodowego w Warszawie. Katalog wystawy. Warszawa: Muzeum Narodowe.

Pospiszil A. Dawno, dawno temu... dostępny na: http://www.anula.pl/dawno-dawno-temu.html.

Suchodolski B. (1965). Współczesne problemy wychowania estetycznego. W: Wojnar I. (red.). Wychowanie przez sztukę. Warszawa: Państwowe Zakłady Wydawnictw Szkolnych.

Szuman S. (1969). O sztuce i wychowaniu estetycznym. Warszawa: Państwowe Zakłady Wydawnictw Szkolnych.

Wojciszke B. (2002). Człowiek wśród ludzi. Zarys psychologii społecznej. Warszawa: Wydawnictwo Naukowe Scholar.

Wojnar I. (1966). Perspektywy wychowawcze sztuki. Warszawa: Nasza Księgarnia.

Wojnar I. (1976). Teoria wychowania estetycznego - zarys problematyki. Warszawa: Państwowe Wydawnictwo Naukowe.

Wolf P. (2001). Creativity and chronic disease Vincent van Gogh (1853-189o). „Western Journal of Medicine", nr 5, s. 348.

\title{
PERSONS WITH DISABILITIES IN WORKS OF ART - PEDAGOGICAL APPROACH
}

\begin{abstract}
Attitudes towards people with disabilities are a common topic of research. In this article the author focuses on the possibilities of shaping positive attitudes towards disabled people through contact with works of art. Education through art was handled as a tool to work with students who have a chance to change their perception of disability by stereotypes.
\end{abstract}

Key words: attitudes, people with disabilities, education through art

Katarzyna Szolc - studentka II roku studiów magisterskich na kierunku pedagogika społeczna z socjoterapią na Wydziale Etnologii i Nauk o Edukacji Uniwersytetu Śląskiego 
w Cieszynie, a także słuchaczka studiów podyplomowych z arteterapii i terapii pedagogicznej na Akademii Pedagogicznej w Warszawie. Jej zainteresowania naukowe skupiają się wokół arteterapii, wychowania estetycznego, edukacji międzykulturowej, pedagogiki porównawczej oraz edukacji alternatywnej. Współautorka artykułu Edukacja międzykulturowa w praktyce - bibliodrama i metody twórcze w bielskim „Teatrze Grodzkim”. Adres e-mail:kmszolc@gmail.com. 